\title{
A Case Study Exploration of Blue-Collar Worker Retirement Plan Investment Decisions
}

\author{
Mark Griffin \\ Embry Riddle Aeronautical University \\ Steven Tippins \\ Walden University
}

\begin{abstract}
The finances of blue-collar workers were the most acutely impacted as these workers lost their jobs during the Great Recession of 2007 through 2009. The literature revealed a minimal understanding of how blue-collar workers allocated funds for their retirement, and what their investments might be when they invested. To address this problem, the current qualitative study addressed (a) how blue-collar workers chose to invest or not invest for retirement and (b) how blue-collar workers diversified their portfolio if they chose to invest. Theoretical foundations of the study were based on regret theory and prospect theory. A nonrandom purposeful sample of 10 blue-collar worker participants answered 19 open-ended questions. Data from these questions were analyzed inductively. Findings revealed that, as participants reached the age of 30, they started to consider investing for their retirement. Participants under the age of 30 were not as likely to invest. Only one person over the age of 30 did not invest for retirement. The factors that contributed to these blue-collar workers' investment decisions for retirement were based on an employer-provided retirement accounts, the fear of running out of money later in life during retirement, and the addition of new family members. One of the most popular retirement investment products for the participant group, which included mechanics, laborers, and material movers, was the U.S. Treasury bonds. Other popular investments were mutual funds, 401(k)s, and IRAs. These findings may inform researchers who are conducting a study on the investment decisions of blue-collar workers. The findings can also be beneficial for other blue-collar workers by showing them that other blue-collar workers do invest, and by revealing their rationales in doing so.
\end{abstract}

Keywords: retirement decisions, blue collar, regret theory, prospect theory, qualitative

\section{Introduction}

Nearly $35 \%$ of U.S. households indicated that saving for their retirement was their most important savings goal, and in 2008, roughly 50 million American workers were actively investing in their 401(k) plans (Holden \& VanDerhei, 2010). At the end of 2008, 401(k)s were valued at approximately $\$ 2.3$ trillion, represented $16 \%$ of all retirement assets, and they equaled about $6 \%$ of the U.S. households' financial assets (Holden \& VanDerhei, 2010). As the economy recovered from the recession of 2007 through 2009, many workers found themselves unemployed, underemployed, or categorized under other forms of labor underutilization (Sum, Khatiwada, McLaughlin, \& Palma, 2010) likely made it increasingly difficult to allocate funds for their retirement. At the heart of the 
ranks of the unemployed were blue-collar workers, and this group was unevenly made up of both men and women workers.

From the periods that covered November through December of 2007 to January through February of 2010 , the male employment declined by 5.67 million or $7.2 \%$ versus a drop of 2.17 million or $3.2 \%$ among women (Sum et al, 2010). This loss of blue-collar employment would account for $81 \%$ of the decline in jobs for men during this period (Sum et al, 2010).

Although not all blue-collar workers found themselves unemployed, they were subject to the overall purchasing decisions made by people in the global and U.S. economy. The sentiments, attitudes, financial capacity, and subsequent behaviors of consumers represented a substantial part of the U.S. national economy (Cutler, 2013). Many of the products that were purchased by people were previously made by factory workers and laborers, and other people who fell into the blue-collar category, were created either with the helped of technology or manufactured entirely through the use of machines (Brown, 2012). This included the manufacturing positions that were held at one time by these workers became automated.

While there was an abundance of literature (Ryack, 2011; Pillay, Kelly, \& Tones, 2010; Levanon \& Cheng, 2011) that discussed the ramifications of the recession of 2007 through 2009, little research had been conducted to see if the subsequent recovery had affected the investment behaviors of bluecollar workers. There was only one study (Goetzmann \& Kumar, 2008) found that spoke specifically to blue-collar worker investment portfolio diversification, and they found that blue-collar workers were in the category possessing the least diversified portfolio.

This study addressed this gap in the literature to determine what facets these workers deemed to be necessary to be in place before they allocated resources, including their levels of investment, for their retirement. The information gained from the study could provide useful insights into these facets which could be used by society to have a better understanding of the decision-making process used by blue-collar workers. This could led to a constructive impact on both blue-collar workers and the society they live in, which could lead to positive social changes in both the fields of finance and academia.

\section{Background}

Griffin and Tippins (2014a, 2014b) established the basis for exploring more deeply blue-collar retirement investment decisions. When blue-collar workers considered retirement, family members generally participated in the decision-making process (Ryack, 2011). This included whether to invest or not and how much money would be invested, and built into this decision was the desire to be risk averse (Ryack, 2011). If the decision was made to invest, there were concerns about which retirement products were right for a person or a couple and what decisions couples should make themselves as they age (Tannahill, 2012). Regardless of age, health risks were a cause for concern, as they threatened both the financial survival and the ability of workers to work through the retirement years in the event retirement became necessary (Caban-Martinez et al., 2011). As workers aged and remained in the workforce, they also became increasingly aware of the need to overcome age discrimination as they risked feeling increased levels of being tired and burned out (Gellert \& Kuipers, 2008).

Part of the decision-making process to retire included delaying retirement until later in life. These delays in the decision to retire had implications on the unemployment rates within the economy as 
new workers were unable to enter as easily as a result of older workers remaining in the workforce (Levanon \& Cheng, 2011). One side effect for both younger and older workers, who were unable to find jobs or transition into new careers, was that they were sometimes at risk of entering into early retirement (Pillay et al., 2010). The decision to retire or invest for retirement was also negatively affected by the economic impacts of the recession of 2007 through 2009, as blue-collar workers had severe hardships based on the decline in their employment status (Sum et al., 2010).

Technology also had a role in the employment status of workers who fell into the blue-collar category (Brown, 2012). Tasks that used to be completed by these workers, such as cutting a piece of metal or managing a warehouse, were embedded in a machine through the use of software. In many cases this eliminated workers or reduced the amount of skill and pay needed to fill a job. Since the 1970s, the inflation adjusted median income of working age households had been slowing (Brown, 2012).

One gap in the knowledge was based on the investment behaviors of blue-collar workers. Little research had been conducted on these workers to explain their current financial plans and preparations for retirement. This included the facets that were necessary to determine their levels of investment. Very little was known about the process that these workers used to made their investment plans. This study addressed this gap in knowledge. The necessity of the study stemmed from the need to understand the circumstances surrounding the decision of blue-collar workers to determine their level of investment for their retirement, and with that information in hand, society as a whole could had a more in-depth understanding of an understudied aspect of the life of these workers.

\section{Problem Statement}

The significant problem the research addressed was the minimal understanding, which included a gap in the area of finance-based research of blue-collar workers, of the facets that these workers deemed necessary to be in place for them to allocated funds for their retirement (Sum et al, 2010). Many reasons exist for people to refrain from investing and saving for their retirement, and, as previously mentioned, there was a gap in the knowledge base where investing literature generally stopped short of extensively covering the investment behaviors of blue-collar workers.

There were also microeconomic implications of individuals who delayed their retirement, and some of them were mixed, which led to the delaying of the retirement decision (Levanon \& Cheng, 2011). The financial risk tolerance (FRT) of males and females varies, whereby males had more tolerance than women, and people potentially sought out mates who had a similar FRT (Ryack, 2011). It may have also been possible that spousal FRTs converged over time. These tolerances increased in college students who had financial education incorporated in the curriculum in high school (Ryack, 2011), but this did not provide long-term evidence that families would have FRT that was similar or based on convergence going forward.

\section{Purpose of the Study}

The purpose of this case study was to discover the factors that contributed to the decision by bluecollar workers to allocated funds for retirement, and it included their investment choices if they invested. Because these workers fell into various employment circumstances, and as a result of the economic downturn and slow recovery, there was a wide variety of reasons that were unknown for making or not making these investments (Sum et al, 2010). This study used prospect theory (Kahneman \& Tversky, 1979) and regret theory (Loomes \& Sugden, 1982) as a theoretical basis for 
the research to uncover these reasons. Prospect theory is a theory based on behavioral economics describing ways people made choices based on losses and gains versus the final outcome, and it asserted that people evaluated losses and gains using heuristics (Kahneman \& Tversky, 1979). Regret theory implies that if people made a wrong choice, they remembered this choice the next time they made another decision under a similar set of circumstances (Loomes \& Sugden, 1982).

\section{Theoretical Foundation}

\section{The Blue-Collar Worker}

Blue-collar workers have been underserved throughout the years by the research community as a whole (Mcleod, Lavis, MacNab, \& Hertzman, 2012; Nielsen \& Abildgaard, 2012; Strandholm, Schatzel, \& Callahan, 2013). At the time of the writing of the dissertation (Griffin, 2015), this work was based on, there were no examples of the theories that are about to be explained that were based on work done with the blue-collar worker community. Limited research (Boris, 2010; Sanders \& McCready, 2009) attempts were made within the last 10 years, as will be explained later in more detail, which discussed the blue-collar workers and their retirement decisions. Two different areas where the research indirectly covered blue-collar workers were severance packages and unemployment and mortality rates.

\section{Blue-Collar Worker Severance Packages}

One such example of severance packages was the study (Strandholm et al, 2013) where the company would attempt to offer four different severance packages to its blue-collar workers, based on a variety of variables to include age and length of employment with the current company, in order to determine which workers would pick a given package and their reasoning behind their choice. The first choice was based on a retirement-eligibility incentive where the employee was offered a bonus. The second option was based on a paid retirement furlough for those employees who were within 2 years of retirement. The third option was a bit more specific and its detail. It was offered to employees who were a minimum of 55 years or older with at least 10 years of credited service, whereby these employees were offered their accrued pension benefits along with other temporary benefits that would be payable to them until the age of 62 . Because the years of service were truncated, these individuals would not get their full retirement pensions as part of the reduced benefit. The final option, which was extended to all employees, was a lump sum payment in exchange for being terminated from the company.

\section{Blue-Collar Worker Unemployment and Mortality Rates}

Another example of research on blue-collar workers (Mcleod et al., 2012) looked at the unemployment rates and mortality rates of workers in Germany and the United States. The researchers (Mcleod et al., 2012) examined the relationship between unemployment and morality in Germany, which they considered to be a coordinated market economy, and the United States, in which they viewed as a liberal market economy. They found that there was an unemployment morality association among American employees but not among the German employees. 


\section{Why People Save}

\section{Personal Savings}

In order to begin the literature review, it was appropriate to provide a better understanding of why people save. One reason, which is not always on the forefront of the mind of someone who is planning for the future, is to plan on paying for their children to go to college (Kim, Huang, \& Sherraden, 2014; Friedline \& Rauktis, 2014). It would also be difficult to compartmentalize them. Instead, three primary topics were presented together. Saving money takes many forms, and people do this for a variety of reasons based on things such as the fulfillment of personal savings goals, the avoidance of having to borrow money to pay for things in the event of an emergency, and even to prevent financial hardships arising from the loss of income stemming from unemployment or retirement (Soman \& Cheema, 2011; Xi, Scholer, \& Higgins, 2014; Burman, Coe, Pierce, \& Liu, 2014; Marucci-Wellman, Willetts, Tin-Chi, Brennan, \& Verma, 2014).

According to Soman and Cheema (2011), who studied the effects of earmarking money on savings for retirement by low-income consumers, creating a savings goal and posting it in a visible are served as a positive visual reminder and increased the propensity for saving; furthermore, they also found that people saved more when earmarked money was partitioned into two accounts than when it is pooled into one account.

The way goals were framed also had an effect on how people saved. Research (Ülkümen \& Cheema, 2011) shows savings could be increased or decreased merely by changing the way people think about their savings goals. This was accomplished by either specifying or not specifying an exact amount to save, and savers would focus on either how or why to save (Ülkümen \& Cheema, 2011; Burman et al., 2014; Marucci-Wellman et al., 2014). The levels of savings had also been on the rise as part of the recovery of the Great Recession of 2007 through 2009 (Walden, 2012; Burman et al., 2014; MarucciWellman et al., 2014), but there was limited evidence of this being a trend for blue-collar workers.

For blue-collar workers specifically, it was difficult to account for specific reasons for the decisions to have a personal savings based on the limited amount of research conducted so far as presented earlier. One reason for this was the low wages that blue-collar workers earn, which had continued to be reduced over time as their jobs were outsourced to foreign competitors adding to a rise in wage difference between educated and non-educated workers (Kosteas, 2008). Risk of losing a job or missing out on a promotion also plays a role in how people save (Xi et al., 2014; Marucci-Wellman et al., 2014).

\section{Retirement}

According to apRoberts (2009), the retirement system in the United States was made up of two main components, which were (a) the federal Social Security system and (b) a myriad of occupational pension plans for employees. These two components did not account for individual broker accounts, where people could buy individual stocks, bonds, and other investment products themselves since apRoberts did not included them. One such example was how occupational pension plans covered a large part of full-time employees in the public sector, but these plans had dropped in coverage in the private sector (apRoberts, 2009). At their height, pension plans covered $40 \%$ of private sector employees, whereas, at the time of the writing of this article, the current amount was approximately $20 \%$ (apRoberts, 2009). 
It should be noted that, whereas only about 17 per cent of employees work in the public sector, public sector pension plans provide practically as much retirement income as private sector pension plans: 8.7 per cent of the total as compared to 8.8 per cent. (apRoberts, 2009, p.620)

apRoberts (2009) also argued that pensions may dwindle as a result of potential cutbacks in Social Security and the decline of occupational pensions. This could lead to older people working more in order to maintain their retirement incomes, but the recent financial crisis tends to discourage attempts to save more for their retirement (apRoberts, 2009). In the event that the parent company was refraining from hiring new employees, existing employees would have a higher workload because additional staff would likely not be brought on to assist with taking care of those tasks. It would also likely hinder promotions that would normally be seen as employees move from one company to another.

\section{Social Safety Nets}

As a result of the near depletion of the reserves allocated for Social Security in the 1980s, and the potential future depletion of the reserves again around the year 2037, there is a growing concern about the health and safety of the ability of Social Security to be an effective safety net (apRoberts, 2009; Brown, Coronado, \& Fullerton, 2009; Marucci-Wellman et al., 2014). There were also public concerns that future entitlement reforms may reduce the amount of Social Security benefits that people would be eligible to receive, and this causes concern among potential and existing recipients that they may not be able to avoid such cuts (Etzioni, 2011).

One such explanation that was a basis for concern was that the Social Security system was the largest government program in the United States (Brown et al, 2009). It accounted for about a quarter of all federal revenue, and it was a major tax on working individuals. A progressive retirement benefit schedule replacing higher fractions of past earnings for those with low earnings was the most important source of income for the elderly. This is because, as it constituted approximately $40 \%$ of all income going to individuals aged 65 and over, and it was designed to essentially be part of the social safety net (Brown et al, 2009).

People generally question whether or not Social Security would available for them at retirement (Brown et al, 2009). This study, however, did not intend to cover this issue in its entirety. Instead, the issue of the safety net was necessary to raise the point that individuals may adjust their saving habits over time with the intentions of supporting themselves through retirement. This topic did apply to blue-collar workers, and it was presented later as evidence of existing literature (Mcleod et al., 2012; Nielsen \& Abildgaard, 2012; Strandholm et al., 2013), blue-collar workers entering retirement early or collecting Social Security benefits.

Unemployment benefits were also categorized as a social safety net (Bitler \& Hoynes, 2010). Prior to the unprecedented increase of unemployment insurance benefits to 99 weeks, resulting from the 2007 through 2009 recession and economic downturn, an individual would only expect to receive about 26 weeks of unemployment payments (Schwartz, 2013). There were also lifetime limits to the individuals in the United States, where they would only be able to expect prolonged unemployment benefits during periods of economic downturn, whereas other countries provide benefits that insure the unemployed for long periods of time regardless of the economy (Schwartz, 2013, p. 700).

It was also difficult to determine whether or not blue-collar workers use unemployment benefits since income was often misreported in household surveys, especially among the most disadvantaged 
households, with only half of food stamp and welfare dollars being reported in mainstream surveys (Bitler \& Hoynes, 2010, p. 138). This also made it difficult to understand rates and levels of savings by blue-collar workers.

\section{Research Design and Rationale}

These were the central research questions that were used in the study:

1. What factors contributed to the decision by blue-collar workers to invest or not invest for retirement?

2. How did blue-collar workers diversify their portfolio if they chose to invest?

These were the subquestions that were used in the study:

1. How much financial education did blue-collar workers feel they needed before investing?

2. In what ways did blue-collar workers' level of academic education affect their levels of investing?

3. In what ways did economic conditions in the local area blue-collar workers were employed cause them to create their overall investment strategy?

4. In what ways did blue-collar workers' age and gender affect their retirement planning?

5. What were the different categories, and how much of each category of investments, did bluecollar workers allocate their money?

\section{Participant Selection Logic}

The participants were blue-collar workers located in the Inland Northwest and Midwest regions of the United States. One metric we used, for the purposes of specificity of saturation, was when there were repetitive themes and no new information was obtained. The goal was to have a minimum of 10 participants to participate in the study, and that goal was met once there were no more participants were willing to take part in the research. There was also no new meaningful information that was being collected near the end of the study since the findings seemed to be fairly consistent throughout the participants' answers.

Because we were transcribing their answers from phone calls that were recorded and writing notes down from the phone calls that were not recorded, it would not have made sense to use NVivo to generate codes and look for themes because the data was recorded in two different ways. Another change to the research that caused this to happen was the inability to gather participants from an organization that would allow us to come into the work place and recruit participants. Instead, we used the snowball sampling technique, and the answers to the questions were compiled into two separate tables and placed into categories listed primarily by age. This was done in order to show how the responses varied in a way that was logical at the time of the writing of this dissertation. It also allowed for the trend of choosing to invest based on the proximity to retirement between the participants, which was not necessarily how they viewed their own retirement investment decisions throughout the interviews. 
It should be noted that the point of this case study was not to generalize the findings across a broader population, which would be seen in quantitative research (Creswell, 2013). Instead, it was the intention of this inquiry to discover what responses could be retrieved from participants in order to answer the research questions. The information that was found in a qualitative case study, as part of a discovery process, could provide rich opportunities for further research that could perhaps be completed using quantitative inquiry.

The criterion for selecting participants was based on whether or not the applicants fell into the category of being a blue-collar worker. Blue-collar workers were generally defined as, but not limited to, workers in construction crafts, machinists, manufacturing, production, laborers, transportation operatives, and material movers (Sum et al., 2010). Individuals were identified locally by locating private companies or governmental agencies in the Inland Northwestern and Midwestern region, and we made contact with either the owner of the business, union representative or the seniorranking governmental official responsible for the workers, and we asked permission to interview to the blue-collar employees who volunteered to be a part of the study. Ultimately we were not allowed to enter into a company to do the study. However, volunteers contacted us and the snowball sampling technique was used to find additional participants for the study.

\section{Study Results}

The first central research question was, "What factors contributed to the decision by blue-collar workers to invest or not invest for retirement?" There were 15 questions that were asked to participants based on this central research question. Where applicable, the results are pooled into Table 1 with further explanation located below the questions presented here:

- What is your age?

- What is your gender?

- How would you describe your financial education? Please explain.

- Describe the amount of financial education you would have to obtain before you would consider investing your money for your retirement. Please explain.

- What is your highest level of academic education? Please explain.

- Do you, or your family, have a budget? Please explain.

- What general occurrence(s) has to happen in your life, or did happen, for you to invest for your retirement? Please explain.

- Regardless of whether or not you are an investor in the stock market, in what ways do you feel that your academic education would affect your choice to invest for your retirement? Please explain.

- What is your opinion of individual stocks of U.S. companies in the U.S. stock market? Please explain.

- What is your opinion of individual stocks of non-U.S. companies in the U.S. stock market? Please explain.

- In what ways does your opinion of the current U.S. economy affect your decision of whether to invest for your retirement? Please explain. 
- In what ways does the current state of the U.S. economy affect your family budget? Please explain.

- In what ways does the economy in your local area affect your decision of whether to invest for your retirement? Please explain.

- Looking ahead, how do you think you will be financially a year from now, will you be better off, worse off, or about the same? Please explain.

- Looking back, would you say that you are financially better off, worse off or about the same as you were a year ago? Please explain.

Explained in further detail below in Table 1, the age ranges of the participants were from 20 to 52, and there were three female participants and seven male participants. Three people, all male participants, said that they had formal financial education. This included three people who had taken a financial budgeting and planning course in high school, and one person had taken a financial investing seminar. The remaining participants indicated that they had no formal financial education; however, one person who did not fall had no formal financial education said, "I have no formal financial education, however I do have a good grasp on finance" (Respondent 9, personal communication, September 7, 2014).

Only four people indicated that financial education would not be necessary prior to making a decision to invest for their retirement. None of those respondents was female, and one female respondent, Respondent 6 , indicated that she would not invest unless she was guaranteed to make money. Respondent 9 indicated that he did not think it was necessary to have formal financial education. Instead, it was only necessary to trust the people who were managing the money, whereas Respondent 5 stated that he did not trust anyone with his money because he had known too many people who had lost money in the stock market in the past. Finally, Respondent 8 was afraid of running out of money in retirement so he felt that he had no other choice but to invest.

The highest levels of academic education indicated by the respondents ranged from high school to one participant who just finished his bachelor's degree. All of the participants had completed high school, and none indicated that they had earned a General Education Development diploma. Three respondents had trade school education. Six respondents, including three female participants and three male participants, said that they have budgets. The other respondents said that they either did not have a budget or they tried to follow one but were frequently unsuccessful. As shown below, the responses were varied between participants when asked whether they were better off, worse off, or about the same from a year ago. The responses were also varied when asked the same question with the exception of how they believe they would fare in a year from now. 


\begin{tabular}{|c|c|c|c|c|c|c|}
\hline Age & Gender & $\begin{array}{l}\text { Has a } \\
\text { budget }\end{array}$ & $\begin{array}{l}\text { Highest level of } \\
\text { academic } \\
\text { education }\end{array}$ & $\begin{array}{c}\text { Has financial } \\
\text { education }\end{array}$ & $\begin{array}{c}\text { Better off (1), } \\
\text { worse off (2), or } \\
\text { about the same } \\
\text { (3) from } 1 \text { year } \\
\text { ago }\end{array}$ & $\begin{array}{l}\text { Better off (1), } \\
\text { worse off (2), or } \\
\text { about the same } \\
\text { (3) } 1 \text { year from } \\
\text { now }\end{array}$ \\
\hline 20 & Male & No & High school & Yes & 1 & 2 \\
\hline 23 & Male & Yes & Some college & Yes & 1 & 1 \\
\hline 24 & Female & Yes & Some college & Yes & 3 & 1 \\
\hline 26 & Male & No & Bachelor's & Yes & 1 & 1 \\
\hline 29 & Male & No & Trade school & No & 1 & 3 \\
\hline 30 & Female & Yes & Trade school & No & 3 & 1 \\
\hline 38 & Female & No & Some college & No & 1 & 1 \\
\hline 47 & Male & Yes & High school & No & 3 & 3 \\
\hline 52 & Male & Yes & Trade school & No & 3 & 1 \\
\hline$\underline{52}$ & Male & Yes & Some college & Yes & 3 & 1 \\
\hline
\end{tabular}

When asked about the general occurrence(s) that had to happen, or did happen, for the decision to be made to start investing for retirement, there were a variety of reasons given. Participant 10 stated that he and his wife realized that they needed to start saving for their retirement after they had their first child. Respondent 1 indicated that he would have to be more educated about finance, along with securing a higher paying job, before he would invest. Three participants indicated that they did not want to run out of money in retirement, and Respondent 3 said she was afraid to be like a family member whom she saw die poor. Two participants indicated that they started investing because their employer offered $401(\mathrm{k})$ matches. The remaining participants did not want to invest because they did not trust the stock markets.

When asked how academic education affects the choice to invest for retirement, four participants indicated that it did have an effect on their decision to invest. Some of the reasons cited included the fact that academic education made them more comfortable understanding finance based on the courses in finance and economics that were taken (Participant 10, personal communication, September 5, 2014; Participant 4, personal communication, September 5, 2014) and the ability to speak to students and professors about their opinions on the markets and companies (Participant 4, personal communication, September 5, 2014); one participant (Participant 1, personal communication, September 7, 2014) indicated that it affected it a lot but could not articulate why. It seemed that he was generally uncomfortable investing based on his other answers throughout the interview. Finally, another participant (Participant 6, personal communication, September 8, 2014) indicated that she would not be comfortable investing because she does not know much about stocks and the stock markets. The remaining six participants indicated that they needed to invest, for a variety of reasons (mainly to fund retirement), so they would/did invest anyways.

Participants were asked to provide their opinions about the individual stocks of both U.S. and nonU.S. companies in the U.S. stock market. Nine out of 10 participants indicated that they did not know enough about the stock market itself, or the individual companies listed for sale there, to answer the question. One participant stated that even though he did not know much about the U.S. and non-U.S. companies he would still invest with the help of a financial planner. 
The participant who did offer an opinion on the two categories of stocks said this of U.S. stocks: "Some companies are safe and some are not. We must look at diversifying risk to different sectors and type and sizes of companies" (Participant 10, personal communication, September 5, 2014). When asked about non-U.S. stocks, he said, "I generally do not trust non-U.S. companies, because of the volatility of exchange rates and general political instability of the world" (Participant 10, personal communication, September 5, 2014).

When asked about how the current U.S. economy affects the decision of whether to invest for retirement, all 10 participants indicated that it made a significant impact on their overall decision. One participant (Participant 2, personal communication, September 6, 2014) indicated that he was worried that the United States may enter into a second recession, and, as a result, he was trying to save more money so that in the event that he lost his job, he would have cash on hand to pay bills and buy groceries. Another participant felt he would lose more money this time if he was still investing in the stock market and felt that he would be better off paying down debt, while another participant (Participant 7, personal communication, September 6, 2014) felt that she would not want to invest in this economy because it was too shaky and wants it to be more stable. Finally, one participant felt that a person would have to be rich to invest in the current economy.

When asked how the U.S. economy affects their budget, one participant said that she was unable to save as much money as she would like because prices in her area for various items that she purchases, including groceries, were going up. Two participants said it does not affect them at all. Another participant said he was recovering from losing $\$ 50,000$ on a house that he had to sell, and he also said that he had a tough time finding a reasonably-paying job in his area. So he had to take the job he has now working at an ice distribution company. The other participants said that they were afraid of the economy crashing again so instead of spending money on things that they would like to buy they find themselves holding off and saving the money.

Many of them said that they would likely start buying things and spending their money again once the economy got better because they were not sure over the long term how long they would get to keep their jobs. Some of the participants also reiterated that they are not good with sticking to a budget regardless of what the economy is doing, while a couple of the participants reiterated that they do not have a budget in the first place. Finally, one participant indicated that he cannot save money because he has too many medical bills to pay.

The general answers between the participants were the same when they were asked the question regarding the local economy and its effect on their decision of whether to invest for retirement. The ones that did not invest feel that the local economy did not necessarily have anything to do with it, and the ones who were investing basically said the same thing except for a few respondents that felt the local economy made them feel comfortable investing because they live in a tourist town in South Dakota. As one respondent put it, "We are an anomaly because of where we are located. We are very fortunate! So I make sure to invest as much and as often as I can" (Participant 9, personal communication, September 7, 2014).

Participants were asked whether they would be better off, worse off, or about the same in a year from now. They were also asked whether they would be better off, worse off, or about the same from a year ago. Only one participant felt he would be worse off in a year from now, and that was because he planned on going back to school and not working as much so that he could focus his time and energy on his course work. 
A couple of participants felt they would be better off in the future because they planned on relocating to another place where they felt they either had better job opportunities or would like the area better. One trend that was noted was that those who reported they went to college or had a degree thought they would be better off in a year from the time of the interview. Only three people, two male participants and one female participant, reported that they would be better off in the future and that they were better off than they were in the past.

The second central research question was, "How did blue-collar workers diversify their portfolio if they chose to invest?" There were four questions that were asked to participants based on this central research question. Where applicable, the results are pooled into Table 2 with further explanation located below the questions presented here:

- Do you currently invest for your retirement? Please explain.

- If you currently invest for your retirement, what do you invest in? Please explain.

- What other types of investment products (i.e. U.S. Treasury bonds, mutual funds, or perhaps other investments), if any, have you invested in for your retirement?

- What percentage, if any, would you say you have in each investment product? Please explain.

Participants were asked if they invest or not, what they invest in, and how much they invest with respect to the percentage of the amount invested per investment product. Out of the participants who are not currently investing, the main investment product they have either purchased (i.e. invested in) was a U.S. Treasury bond. One participant indicated that he only buys U.S. Treasury bonds but he wants to buy mutual funds in the future. Another participant (Participant 3, personal communication, September 5, 2014) indicated that she invests $\$ 200$ per month into a mutual fund. When asked what other investment products they had invested in, they all reiterated what they currently invest in because it is what they have chosen in the past or they said that they had bought U.S. Treasury bonds in the past or these bonds were given to them by family members.

Table 2: Blue-Collar Worker Investment Decisions

\begin{tabular}{lcccc}
\hline Age & Gender & $\begin{array}{c}\text { Invests for } \\
\text { retirement }\end{array}$ & $\begin{array}{c}\text { Investment product } \\
\text { of choice }\end{array}$ & $\begin{array}{c}\text { Percentage allocated } \\
\text { if known }\end{array}$ \\
\hline 20 & Male & No & N/A & N/A \\
23 & Male & Yes & $\begin{array}{c}\text { U.S. Treasury } \\
\text { bond }\end{array}$ & $100 \%$ \\
& & & Mutual fund & $100 \%$ \\
24 & Female & Yes & N/A & N/A \\
26 & Male & No & N/A & N/A \\
29 & Male & No & $401(\mathrm{k})$ & $100 \%$ \\
30 & Female & Yes & N/A & N/A \\
38 & Female & No & IRA and U.S. & $80 \% / 20 \%$ \\
47 & Male & Yes & Treasury bonds & $100 \%$ \\
52 & & & $401(\mathrm{k})$ & $70 \% / 25 \% / 5 \%$ \\
52 & Male & Yes & Mutual fund, IRA, & \\
& Male & Yes & $401(\mathrm{k})$ &
\end{tabular}

Note. N/A = not applicable. 
Overall, based on the answers provided by 10 different research participants who were located in Washington State, North Dakota, and South Dakota, their particular investment choices, opinions, and reasons for doing or not doing something or feeling a certain way were overall nonconfirming based on the given research conducted. This would mean that answers were varied from question to question, but some consistencies, as described and presented above, did arise in the findings. It also meant that the answers would not always be the same, or redundant, as one might find in qualitative research. So the answers to the questions that could be placed into a table were done so above in two different segments to illustrate the responses by the participants.

Some things could not be illustrated in the tables. For example, one participant indicated that she would not feel comfortable investing in something that does not guarantee a return. However, even though she indicated she would not be comfortable investing, she later indicated that she does actually invest because her company offers it and she can fit it in her budget. This also provides further proof that a given research would not be able to replicate the findings of the study given the varied answers from one person to another.

\section{Conclusions}

The reason this case study was chosen was because it involved a category of society that was underserved. The purpose of this case study was to discover the factors that contributed to the decision by blue-collar workers to allocate funds for retirement. This also included an attempt to discover how the blue-collar workers would invest their money, to include what they would buy and how much of it, in order to better understand their investment choices. Because these workers fell into various employment circumstances, and as a result of the economic downturn and slow recovery, there was a wide variety of reasons that were previously unknown for making or not making these investments (Sum et al, 2010). However, in many cases, the blue-collar workers seemed to have had similar investment habits than people who did not fall into that category. They also seemed to base their choices to invest or not invest based on how well they did or did not understand what they were buying, even though the data collected seemed to indicate that once they reach the age of 30 , there was a higher likelihood that they would invest anyway.

One item that was noted during the collection of the data was that when a participant did make a choice to invest, they seemed to allocate funds in an area that most institutional investors might consider to be a more safe investment and that was the investment in a U.S. Treasury bond. One other item of note that seemed to be part of their overall responses, albeit a response not shared by perhaps one or two participants, was the notion that a person would not invest in something that they do not understand. We posit, based on our brief experience with these participants, that knowledge can dispel fear. That is, the more we know about something, the less we seem to be fearful of it. It seemed to us that the participants who had financial education at a younger age seemed to be more willing to invest even if they were not currently doing it.

Although they did not come out and say that the overall U.S. economy would prevent them for investing for their retirement, one could make the argument that if the U.S. economy had recovered in a more meaningful and consistent way, such as a strong and steady rise in employment and hourly wages noted throughout the entire United States and not just segments of it, then these respondents might have answered differently. Or perhaps they may not have. Not only that, but it might even entirely be possible that they would allocate more money than they currently do as of the time of the writing of this article. 
Based on the strengths and limitations of the current study, as well as the literature review, further research should be directed to other blue-collar communities throughout the United States. This research could be quantitative-based, whereby larger groups of blue-collar workers could participate in surveys that are generated in a similar fashion based on the questions that were asked in this study. It could also be done as a mixed-method study whereby, much in the same manner in which it was conducted here, through a qualitative case study approach using purposeful sampling and/or snowball sampling. Part of the study could take surveys from blue-collar workers located within a geographic region of the state, such as the southwestern region of the country or perhaps somewhere else, and then there could be interviews done with participants where they are asked to answer similar questions where they are allowed to offer in-depth responses.

The literature review discussed a variety of reasons of why people save. Saving money takes many forms, and it did this for a variety of reasons (Xi et al., 2014; Burman et al., 2014; Marucci-Wellman et al., 2014). These reasons were based on things such as the fulfillment of personal savings goals, the avoidance of having to borrow money to pay for things in the event of an emergency, and even to prevent financial hardships arising from the loss of income stemming from unemployment or retirement (Soman \& Cheema, 2011; Xi et al., 2014; Burman et al., 2014; Marucci-Wellman et al., 2014). Based on the interviews, we would say that the interviewees did not always save in the same way that other people do with respect to having an adequate retirement. However, they did plan on emergencies and many of them indicated that they have money in the event that something happens to them (i.e. loss of a job or moving from one location to another).

Further research using surveys into a larger group of these workers, perhaps through the use of quantitative inquiry in different states, could result in a clearer understanding of their investment habits. Perhaps if more light is shed on more of the people in this category with respect to the data that is collected would elaborate on the findings of this study, even though one could make the argument that the results may end up being very similar. One could also argue that the more that is known about this category of worker could be good for the academic community as a whole as well as the blue-collar community.

\section{References}

apRoberts, L. (2009). Trends in the retirement system of the United States. Geneva Papers on Risk \& Insurance: Issues \& Practice, 34, 618-630. doi:10.1057/gpp.2009.28

Bitler, M., \& Hoynes, H. (2010). The state of the social safety net in the post-welfare reform era. Brookings Papers on Economic Activity, 2, 71-147. doi:10.1353/eca.2010.0019

Boris, M. (2010). Fighting for equal treatment. Labor Studies Journal, 35, 157-180. doi:10.1177/0160449X08325994

Brown, A. (2012). Automation vs. jobs. Mechanical Engineering, 134, 22-27. doi:10.1115/1.4025349

Brown, J., Coronado, J., \& Fullerton, D. (2009). Is Social Security part of the social safety net? (Working Paper No. 15070). Retrieved from http://www.nber.org/papers/w15070.pdf

Burman, L. E., Coe, N. B., Pierce, K., \& Liu, T. (2014). The effects of the taxation of Social Security benefits on older workers' income and claiming decisions. National Tax Journal, 67, 459485. doi:10.2139/ssrn. 2530030 
Caban-Martinez, A., Lee, D., Fleming, L., Tancredi, D., Arheart, K., LeBlanc, W., \& Muennig, P. (2011). Arthritis, occupational class, and the aging U.S. workforce. American Journal of Public Health, 101, 1729-1734. doi:10.2105/AJPH.2011.300173

Creswell, J. (2013). Qualitative inquiry and research design: Choosing among five approaches (3rd ed.). Thousand Oaks, CA: Sage Publications. doi:10.1023/A:1023254226592

Cutler, N. (2013). How everybody's consumer opinions interact with the gross domestic product: A brief look at the index of consumer sentiment. Journal of Financial Service Professionals, 67, 19-24. doi:10.1257/jel.45.3.686

Etzioni, A. (2011). The unwarranted attack on social safety nets. Challenge, 54, 108-115. doi:10.2753/0577-5132540406

Friedline, T., \& Rauktis, M. (2014). Young people are the front lines of financial inclusion: A review of 45 years of research. Journal of Consumer Affairs, 48, 535-602. doi:10.1111/joca.12050

Gellert, F., \& Kuipers, B. (2008). Short and long term consequences of age in work teams: An empirical exploration of ageing teams. Career Development International, 13, 132-149. doi:10.1108/13620430810860549

Goetzmann, W., \& Kumar, A. (2008). Equity portfolio diversification. Review of Finance, 12, 433463. doi:10.1093/rof/rfn005

Griffin, M. (2015). A case study of blue-collar worker retirement investment decisions (Order No. 3685617). Retrieved from http://search.proquest.com/docview/1664610870?accountid=14872

Griffin, M., \& Tippins, S. (2014a). Factors that influence the investment decisions of blue-collar workers. Insights to a Changing World Journal, 2014, 42-53.

Griffin, M., \& Tippins, S. (2014b). Retirement investment choices of blue-collar American workers. Franklin Business \& Law Review Journal, 2014, 214-228.

Holden, S., \& VanDerhei, J. (2010). Recent trends in 401(k) participants' asset allocations. Journal of Financial Service Professionals, 64, 76-88. doi:10.2139/ssrn.423992

Kahneman, D., \& Tversky, A. (1979). Prospect theory: An analysis of decision under risk. Econometrics (Pre-1986), 47, 263-292. doi:10.2307/1914185

Kim, Y., Huang, J., \& Sherraden, M. (2014). What shapes assessment of ability to pay for children's college education? Journal of Consumer Affairs, 48, 486-514. doi:10.1111/joca.12049

Kosteas, V. (2008). Manufacturing wages and imports: Evidence from the NLSY. Economica, 75, 259-279. doi:10.1111/j.1468-0335.2007.00591.x

Levanon, G., \& Cheng, B. (2011). U.S. workers delaying retirement: Who and why and implications for businesses. Business Economics, 46, 195-213. doi:10.1057/be.2011.27

Loomes, G., \& Sugden, R. (1982). Regret theory: An alternative theory of rational choice under uncertainty. Economic Journal, 92, 805-824. doi:10.1037/a0019807

Marucci-Wellman, H. R., Willetts, J. L., Tin-Chi, L., Brennan, M. J., \& Verma, S. K. (2014). Work in multiple jobs and the risk of injury in the U.S. working population. American Journal of Public Health, 104, 134-142. doi:10.2105/AJPH.2013.301431

Mcleod, C. B., Lavis, J. N., MacNab, Y. C., \& Hertzman, C. (2012). Unemployment and mortality: A comparative study of Germany and the United States. American Journal of Public Health, 102, 1542-1550. doi:10.2105/AJPH.2011.300475 
Nielsen, K., \& Abildgaard, J. S. (2012). The development and validation of a job crafting measure for use with blue-collar workers. Work \& Stress, 26, 365-384. doi:10.1080/02678373.2012.733543

Pillay, H., Kelly, K., \& Tones, M. (2010). Transitional employment aspirations for bridging retirement. Journal of European Industrial Training, 34, 70-86. doi:10.1108/03090591011010325

Ryack, K. (2011). The impact of family relationships and financial education on financial risk tolerance. Financial Services Review, 20, 181-193. doi:10.5539/ijbm.v8n11p63

Sanders, M., \& McCready, J. (2009). A qualitative study of two older workers' adaptation to physically demanding work. Work, 32, 111-122. doi:10.3233/WOR-2009-0797

Schwartz, J. (2013). Unemployment insurance and the business cycle: What adjustments were needed? Southern Economic Journal, 79, 680-702. doi:10.4284/0038-4038-2010.321

Soman, D., \& Cheema, A. (2011). Earmarking and partitioning: Increasing saving by low-income households. Journal of Marketing Research, 48, S14-S22. doi:10.1509/jmkr.48.SPL.S14

Strandholm, K., Schatzel, K., \& Callahan, T. (2013). Inducing employees to leave: A comparison of four severance options. Human Resource Management, 52, 243-262. doi:10.1002/hrm.21526

Sum, A., Khatiwada, I., McLaughlin, J., \& Palma, S. (2010). The Great Recession of 2008-2009 and the blue-collar depression. Challenge, 53, 6-24. doi:10.2753/0577-5132530401

Tannahill, B. (2012). The role of financial literacy in retirement decision making. Journal of Financial Service Professionals, 66, 32-35. doi:10.3386/w13824

Ülkümen, G., \& Cheema, A. (2011). Framing goals to influence personal savings: The role of specificity and construal level. Journal of Marketing Research, 48, 958-969. doi:10.1509/jmr.09.0516

Walden, M. (2012). Will households change their saving behaviour after the "Great Recession"? The role of human capital. Journal of Consumer Policy, 35, 237-254. doi:10.1007/s10603-0119180-7

Xi, Z., Scholer, A. A., \& Higgins, E. T. (2014). In pursuit of progress: Promotion motivation and risk preference in the domain of gains. Journal of Personality \& Social Psychology, 106, 183-201. doi:10.1037/a0035391

The International Journal of Applied Management and Technology (IJAMT), sponsored by Walden University's School of Management, is a peer-reviewed, online journal that addresses contemporary national and international issues related to management and technology. The objectives of the IJAMT are to: (a) encourage collaborative and multi-disciplinary examinations of important issues in business and technology management, and (B) engage scholars and scholar-practitioners in a dynamic and important dialogue.

Walden University Publishing: http://www.publishing.waldenu.edu 